\title{
CGMP Phosphodiesterase Inhibitor
}

National Cancer Institute

\section{Source}

National Cancer Institute. cGMP Phosphodiesterase Inhibitor. NCI Thesaurus. Code C2127.

Any substance that inhibits cGMP phosphodiesterase, an enzyme that breaks the phosphodiester bond in cGMP. Inhibition of cGMP phosphodiesterase can be used to affect vasodilation. 